\title{
Differential contribution of diatoms and dinoflagellates to phytoplankton biomass in the NE Atlantic Ocean and the North Sea
}

\author{
Sophie C. Leterme ${ }^{1,2, *}$, Laurent Seuront ${ }^{3,4}$, Martin Edwards ${ }^{1}$ \\ ${ }^{1}$ Sir Alister Hardy Foundation for Ocean Science, The Laboratory, Citadel Hill, Plymouth PL1 2PB, UK \\ ${ }^{2}$ School of Biological Sciences, University of Plymouth, Drake Circus, Plymouth PL4 8AA, UK \\ ${ }^{3}$ Ecosystem Complexity Research Group, Station Marine de Wimereux, CNRS UMR 8013 ELICO, \\ Université des Sciences et Technologies de Lille, 28 avenue Foch, 62930 Wimereux, France \\ ${ }^{4}$ School of Biological Sciences, Flinders University, GPO Box 2100, Adelaide, South Australia 5001, Australia
}

\begin{abstract}
Sampling by the continuous plankton recorder (CPR) survey over the North Atlantic Ocean and the North Sea has enabled long-term studies of phytoplankton biomass. Analysis of an index of phytoplankton biomass, the phytoplankton colour index (PCI), has previously shown an increase in phytoplankton biomass in the NE Atlantic. In the current study, further investigations were conducted to determine the contribution of diatom and dinoflagellate cell counts to the PCI, their fluctuations over the last $45 \mathrm{yr}$ and their geographical variations in the eastern North Atlantic and the North Sea. An increased contribution of dinoflagellates to the PCI was revealed over the south NE Atlantic and the northern North Sea. In contrast, the contribution of diatoms decreased in the north NE Atlantic and the northern North Sea. No discernible trends were found in the other regions of the North Sea. The relative contributions of diatoms and dinoflagellates to the PCI led to the identification of 3 geographically distinct dynamic regimes in the diatom/dinoflagellate dynamics in the NE Atlantic and the North Sea. Finally, it is stressed that the discrepancy observed in the patterns of PCI and diatom and dinoflagellate cell counts suggests that changes in PCI do not reflect changes in the community structure and that the exclusive use of PCI is not adequate to investigate the long-term trends in the trophic link between phytoplankton and herbivorous zooplankton.
\end{abstract}

KEY WORDS: Diatoms $\cdot$ Dinoflagellates $\cdot$ PCI $\cdot$ CPR $\cdot$ Long-term changes

\section{INTRODUCTION}

Interannual fluctuations in phytoplankton species composition and abundance have received less attention in the NE Atlantic Ocean than those of higher trophic groups such as zooplankton (Planque \& Taylor 1998, Hays et al. 2001, Lindley \& Batten 2002) and fish (Fromentin et al. 1998, Sims \& Reid 2002, Lindley et al. 2003). Since 1958, several studies have shown an increase in phytoplankton biomass in the North Atlantic (Barton et al. 2003, Leterme et al. 2005), the NE Atlantic (Reid et al. 1987) and the North Sea (Reid 1978, Reid \& Edwards 2001). The overall phytoplank- ton abundance in the NE Atlantic has been shown to be driven mainly by variations in sea surface temperature (Richardson \& Schoeman 2004).

Changes in phytoplankton abundance and/or community composition may impact zooplankton population structure and their predator abundance. This is especially true in a complex marine area including different types of environments from open oceanic waters to epicontinental basins and neritic coastal regions such as the NE Atlantic and the North Sea. In particular, the North Sea is hydrographically divided into different regions, from seasonally stratified waters in the north to tidally mixed waters in the south. Edwards \& 
Richardson (2004) have shown that the response of the marine pelagic community to climate changes in the central North Sea differs throughout the community and the seasonal cycle, leading to a mismatch between trophic levels and functional groups.

The continuous plankton recorder (CPR) survey provides records of the abundance of 500 phytoplankton and zooplankton taxa and provides a visual assessment of phytoplankton biomass, i.e. the phytoplankton colour index (PCI) (Colebrook \& Robinson 1965). Within the phytoplankton, diatoms and dinoflagellates are the main taxonomic groups identified by the CPR survey, consisting of 178 species or taxa. Most phytoplankton taxa have been consistently identified and enumerated since 1958. The PCI has been extensively used to describe the seasonal and long-term patterns of phytoplankton abundance (Reid 1978, Edwards et al. 2001, Batten et al. 2003, Johns et al. 2003) in various regions of the North Atlantic. An increasing trend in phytoplankton biomass has been shown in the North Sea (Reid \& Edwards 2001) and in the area west of the British Isles (Edwards et al. 2001). Different explanations have been formulated to explain this increase, e.g. hydro-climatic processes (Edwards et al. 2001, Richardson \& Schoeman 2004) and eutrophication (Lancelot et al. 1997, Cloern 2001). However, to our knowledge, this increase has not been investigated in relation to the 2 most abundant functional groups within the phytoplankton assemblage, the diatoms and dinoflagellates.

The aim of this study is thus to determine (1) the global trends of PCI and diatom and dinoflagellate abundance, (2) the contribution of the diatoms and dinoflagellates to the PCI, (3) their fluctuations over $45 \mathrm{yr}$ of sampling, (4) their geographical variations in the NE Atlantic and (5) how they may be linked to hydro-climatic variables such as the North Atlantic Oscillation (NAO) and sea surface temperature (SST).

\section{MATERIALS AND METHODS}

The CPR survey is a unique upper layer plankton monitoring programme that has regularly collected samples, at monthly intervals, in the North Atlantic and the North Sea since 1946 (Warner \& Hays 1994). The CPR is a high-speed sampler towed at ca. $20 \mathrm{~km}$ $\mathrm{h}^{-1}$ behind voluntary merchant ships (ships of opportunity, SOOP) at a standard depth of $6.5 \mathrm{~m}$ (Hays \& Warner 1993). An impeller mounted at its rear drives the internal sampling mechanism. Water flows through a $1.62 \mathrm{~cm}^{2}$ aperture in the CPR nose cone, down a tunnel that expands to a cross-sectional dimension of $5 \times$ $10 \mathrm{~cm}$, where it is filtered by a moving band of silk with an average mesh size of $270 \mu \mathrm{m}$. The filtering silk is covered by a second layer of silk and reeled into a storage tank filled with $4 \%$ formaldehyde (to fix and preserve the plankton). The 2 bands of silk move continuously across the tunnel at a speed adjusted according to the speed of the ship, via the impeller and gearbox, to $10 \mathrm{~cm}$ per 10 nautical miles $(18.5 \mathrm{~km})$. The water exits through a rectangular aperture at the rear of the $\mathrm{CPR}$. The $10 \mathrm{~cm}$ of filtering silk approximately corresponds to a seawater volume of $3 \mathrm{~m}^{3}$. After the tow, the CPR is returned to the laboratory for routine analysis. Methods of counting and data processing have been described by Colebrook (1975) and Warner \& Hays (1994). Due to the mesh size of CPR silks, large phytoplankton species are sampled more quantitatively than small species. It has been found, however, that the proportion of the population that is retained by the CPR silk actually reflects the major changes in abundance, distribution and specific composition (Robinson 1970). Despite the near-surface sampling, the CPR provides an accurate representation of plankton dynamics in the epipelagic zone (Lindley \& Williams 1980).

Different groups of phytoplankton taxa have been identified (e.g. diatoms, dinoflagellates, coccolithophores and silicoflagellates), many to the species level. Diatom and dinoflagellate species have been identified and counted in the same way since 1958, while coccolithophores and silicoflagellates have only been enumerated since 1993. It is thus impossible to conduct the same analyses on all these taxa. Consequently, only diatoms and dinoflagellates (i.e. a total of 131 species) were taken into account in the present work, to consistently investigate the period from 1958 to 2002. The abundance of all diatom and dinoflagellate species $(75$ and 56, respectively) identified in the NE Atlantic (Warner \& Hays 1994) was derived by summing the number of cells identified to determine the overall trends of these 2 groups (Leterme et al. 2005).

The potential influence of hydro-climatic variables on phytoplankton fluctuations was investigated using the NAO winter index and the SST. Hurrell's NAO winter index (Hurrell 1995) computes the pressure difference based on measurements from Lisbon, Portugal, and Stykkisholmur, Iceland, from December to March. The SST (HadISST Version 1.1) data were provided by the Hadley Centre, UK Met Office.

The study area (Fig. 1) corresponds to 2 regions identified along a north-south axis: the north NE Atlantic ( 51 to $64^{\circ} \mathrm{N}, 20^{\circ} \mathrm{W}$ to $15^{\circ} \mathrm{E}$ ) and the south $\mathrm{NE}$ Atlantic ( 37 to $51^{\circ} \mathrm{N}, 20^{\circ} \mathrm{W}$ to $15^{\circ} \mathrm{E}$ ). Even if the north NE Atlantic includes the epicontinental North Sea, the latter was considered separately for the purposes of this study and divided into 3 regions along a north-south axis following the limits of the CPR standards area (Colebrook 1975) to take into account the different hydrographical forcing processes (e.g. the 


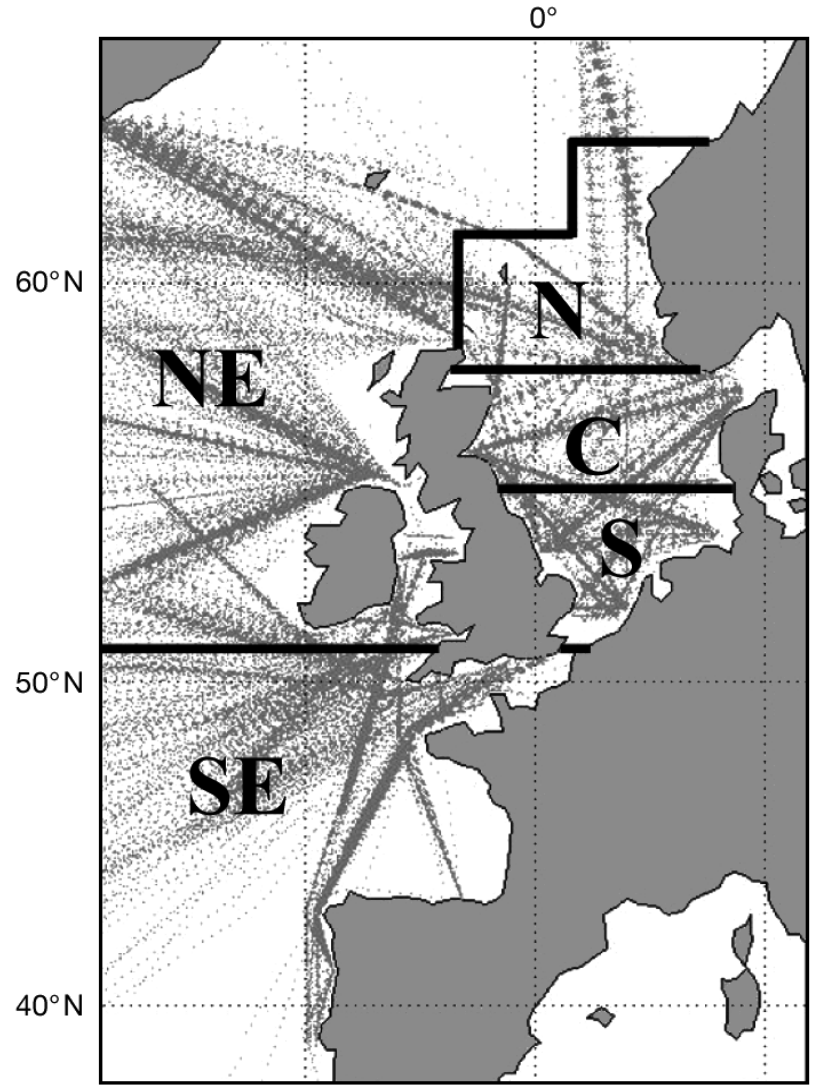

Fig. 1. The NE Atlantic Ocean, divided into north NE Atlantic (NE) and south NE Atlantic (SE), and the North Sea, divided into northern $(\mathrm{N})$, central $(\mathrm{C})$ and southern $(\mathrm{S})$ following the limits of the continuous plankton recorder (CPR) standard area. CPR samples used in this study are shown in grey

northern inflow of Atlantic waters between Scotland and Norway and the southern inflow via the English Channel).

Using the 108951 CPR samples available from 1958 to 2002, annual means of PCI, diatom and dinoflagellate abundance were generated as a preliminary step to detect global trends. More specifically, monthly means of PCI, diatom and dinoflagellate abundance were calculated to investigate details of the relationship between the PCI and diatom and dinoflagellate abundance in the 5 above mentioned areas. To determine the contribution of diatoms and dinoflagellates to the PCI and their variations during the period of study, multiple linear regression analysis (Sokal \& Rohlf 1995, Zar 1996) was conducted between monthly means of PCI, diatom and dinoflagellate abundance for each sampling year. This analysis was performed only on the complete time series of data (i.e. 12 monthly means $\mathrm{yr}^{-1}$ ). As a consequence, when the time series were not complete, our analysis generated missing values in the contribution time series. Thus, 4 and $20 \%$ of the values were missing in the contribution time series for the central and southern North Sea, respectively.
We also stress that because large flagellate species (e.g. Ceratium spp.) and chain-forming diatoms (e.g. Chaetoceros spp.) were undersampled (Warner \& Hays 1994), the sum of the contributions of total diatoms and total dinoflagellates did not always reach $100 \%$.

The residuals of the diatom/dinoflagellate contribution were analysed in order to infer the contribution of other groups to the PCI. Long-term trends in abundance and in the contribution of diatoms and dinoflagellates to the PCI were examined in each region by calculating Kendall's coefficient of rank correlation, $\tau$, between the series and the time in years in order to detect the presence of a linear trend (Kendall \& Stuart 1966). Kendall's coefficient of correlation is used in preference to Spearman's coefficient of correlation, $\rho$, although the latter was recommended in Kendall (1976), because Spearman's $\rho$ gives greater weight to pairs of ranks that are further apart, while Kendall's $\tau$ weights each disagreement in rank equally (see Sokal \& Rohlf 1995 for further developments).

To detect changes and the intensity and duration of any changes in the value of a given parameter, we used the cumulative sums method (Ibañez et al. 1993). The calculation consists of subtracting a reference value (here the mean of the series) from the data; the anomalies are then successively added, forming a cumulative function. Successive positive anomalies produce an increasing slope, whereas successive negative anomalies produce a decreasing slope. Succession of values with little difference from the mean show no slope. This analysis was performed on the time series of annual means in all the areas, but it was performed on the time series of contributions only in the NE Atlantic, due to the excess of missing data for the North Sea.

The relationship between phytoplankton and climate indices was tested through Spearman correlation analysis performed for the NE and SE North Atlantic between the abundance and contribution of diatoms and dinoflagellates and (1) the NAO winter index and (2) the SST. As stated above, these tests were not performed for the North Sea, due to the excess of missing data.

\section{RESULTS}

\section{North NE Atlantic}

In the north NE Atlantic, we observed a significant increase in PCI and a significant decrease in diatom and dinoflagellate abundances (Fig. 2A, Table 1). The cumulative sums revealed different local trends in PCI and diatom abundance, but none for dinoflagellate abundance (Fig. 2C). The cumulative sums of PCI de- 

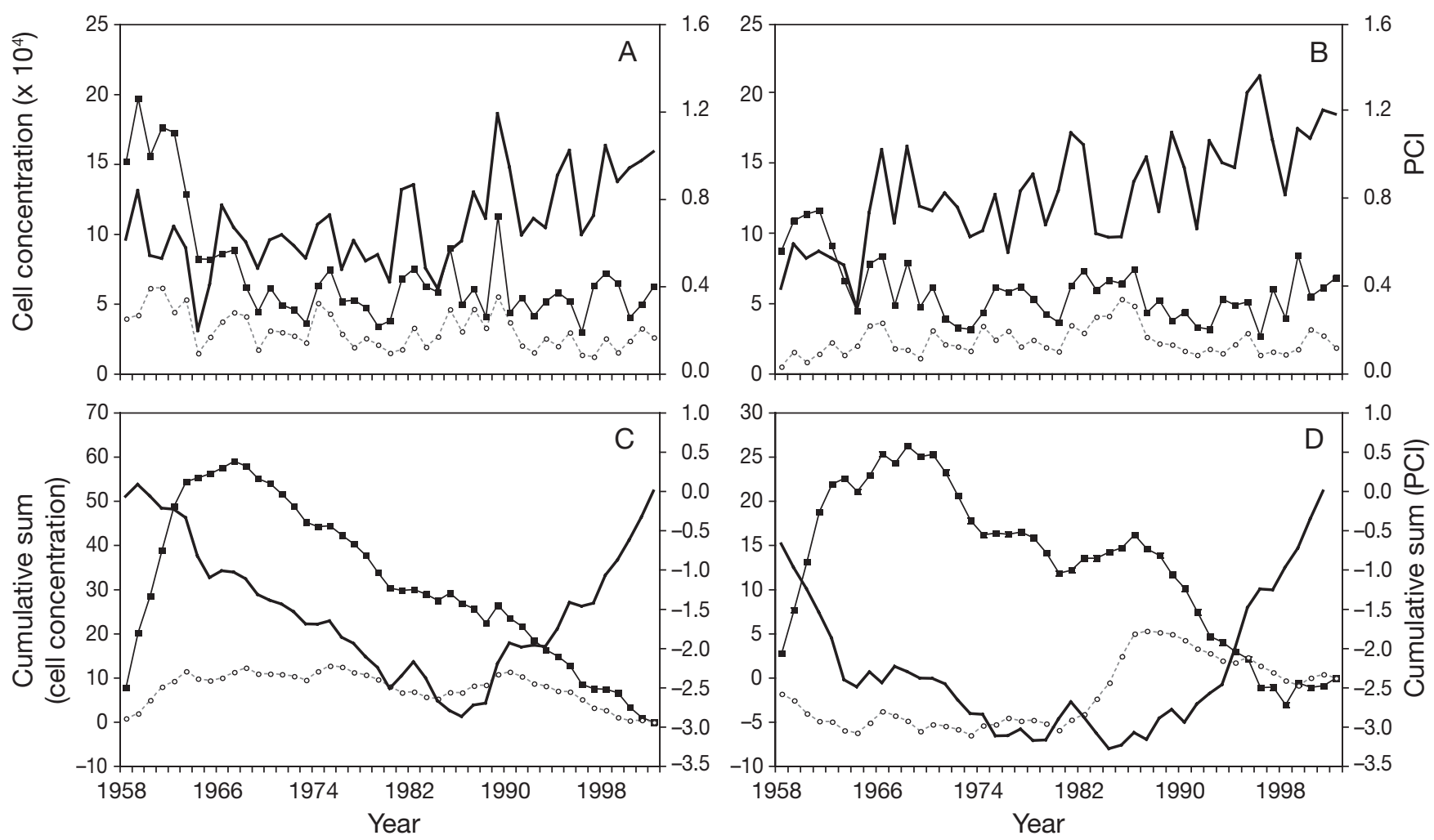

Fig. 2. Variation of annual cell concentrations of both diatoms ( $\bullet$ ) and dinoflagellates (O) and the phytoplankton colour index (PCI; black line) in (A) the north NE Atlantic and (B) the south NE Atlantic Ocean, and the cumulative sum analysis for each parameter in (C) the north NE Atlantic and (D) the south NE Atlantic Ocean

Table 1. Kendall's $\tau$ estimated from the time series of the phytoplanktion colour index (PCI) and diatom and dinoflagellate abundance over the period 1958 to 2002 for the NE Atlantic Ocean and the North Sea. ${ }^{*} 5 \%$ significance level

\begin{tabular}{|lccc|}
\hline & PCI & Diatoms & Dinoflagellates \\
\hline North NE Atlantic & $0.378^{*}$ & $-0.337^{*}$ & $-0.297^{*}$ \\
South NE Atlantic & $0.535^{*}$ & $-0.248^{*}$ & 0.085 \\
Northern North Sea & $0.624^{*}$ & -0.020 & $0.364^{*}$ \\
Central North Sea & $0.386^{*}$ & -0.200 & -0.085 \\
Southern North Sea & $0.329^{*}$ & -0.158 & $-0.242^{*}$ \\
\hline
\end{tabular}

creased and increased, respectively, before and after 1986, while they increased and decreased, respectively, before and after 1967 for diatoms. This suggests a shift in phytoplankton biomass and diatom abundance before and after 1986 and 1967, respectively.

Over the period of study, the contribution of diatoms significantly decreased from 66.14 to $37.54 \%$ (Table 2). In contrast, the contribution of dinoflagellates did not exhibit any significant trend. The residuals of the diatom/dinoflagellate contribution significantly increased from 22.87 to $36.51 \%$ (Table 2 ). In addition, a shift was observed in the phytoplankton community between 1986 and 1996, when dinoflagellates become more dominant than diatoms in the community
Table 2. Kendall's $\tau$ estimated for the contribution of diatoms and dinoflagellates to the PCI, and their residuals over the period 1958 to 2002 for the NE Atlantic Ocean and the North Sea. ${ }^{*} 5 \%$ significance level

\begin{tabular}{|lccc|}
\hline & Diatoms & Dinoflagellates & Residuals \\
\hline North NE Atlantic & $-0.236^{*}$ & 0.190 & $0.232^{*}$ \\
South NE Atlantic & 0.039 & $0.206^{*}$ & -0.177 \\
Northern North Sea & $-0.204^{*}$ & $0.253^{*}$ & 0.114 \\
Central North Sea & -0.038 & -0.054 & 0.104 \\
Southern North Sea & 0.011 & -0.059 & 0.075 \\
\hline
\end{tabular}

(Fig. 3A). This is specified by the cumulative sums, which suggest a period of relative stability in diatom and dinoflagellate contributions from 1958 to 1985, followed by antisymmetric local trends from 1985 to 2002 (Fig. 3C). This suggests a stability of the phytoplankton community composition before 1985.

PCI and diatom abundance have shown a significant positive correlation with NAO and SST, respectively, but no relationships were observed between the climatic parameters and dinoflagellate abundance (Table 3). No relationship was observed between the NAO winter index and the diatom/dinoflagellate contribution to the PCI (Table 4). Conversely, the contribution of dinoflagellates resulted in a significant negative 

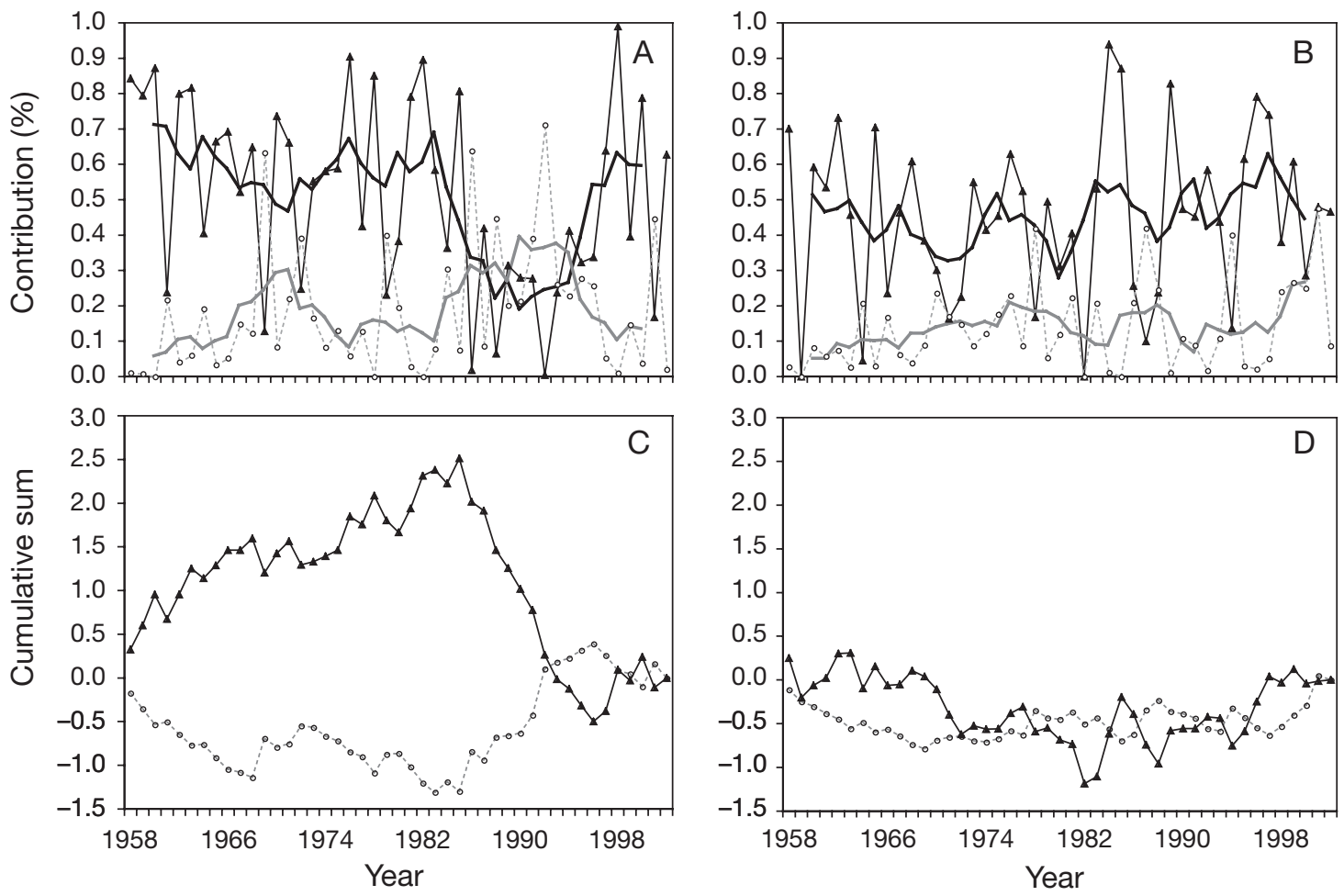

Fig. 3. Dinoflagellate $(O)$ and diatom $(\mathbf{\Lambda})$ contributions to the phytoplankton colour index (PCI) for each year during the period 1958 to 2002 in (A) the north NE Atlantic and (B) the south NE Atlantic Ocean. Bold lines represent the 5 yr running means illustrating the trends in the time series. Cumulative sums of dinoflagellate (O) and diatom (⿶) contribution to the PCI were determined in (C) the north NE Atlantic and (D) the south NE Atlantic Ocean

Table 3. Spearman's $\rho$ estimated between PCI and diatom and dinoflagellate abundance and (1) the North Atlantic Oscillation index (NAO) and (2) the sea surface temperature (SST) over the period 1958 to 2002 for the NE Atlantic Ocean and the North Sea. ${ }^{*} 5 \%$ significance level

\begin{tabular}{|c|c|c|c|c|c|c|}
\hline & \multicolumn{3}{|c|}{ - NAO } & \multirow[b]{2}{*}{ Diatoms } & \multirow{2}{*}{$\begin{array}{c}\text { SST } \\
\text { Dinoflagellates }\end{array}$} & \multirow[b]{2}{*}{ PCI } \\
\hline & Diatoms & Dinoflagellates & PCI & & & \\
\hline North NE Atlantic & -0.114 & -0.031 & $0.378^{*}$ & $0.372^{*}$ & 0.250 & 0.281 \\
\hline South NE Atlantic & -0.207 & 0.161 & 0.263 & -0.017 & -0.054 & 0.170 \\
\hline Northern North Sea & -0.008 & 0.153 & $0.399^{*}$ & -0.028 & 0.076 & 0.155 \\
\hline Central North Sea & -0.143 & 0.018 & 0.179 & -0.119 & -0.028 & $0.302 *$ \\
\hline Southern North Sea & -0.153 & -0.193 & 0.082 & -0.067 & -0.173 & $0.466^{*}$ \\
\hline
\end{tabular}

relationship with SST (Table 4). No significant longterm trend was observed for the SST over the period of study (Kendall's $\tau, \mathrm{p}<0.05, \tau=0.034$ ).

\section{South NE Atlantic}

As previously observed in the north NE Atlantic, we observed a significant increase in PCI and a significant decrease in diatom abundance (Fig. 2B, Table 1). However, no significant decadal trend was identified for dinoflagellate abundance (Table 1). The cumulative sums revealed different local trends in $\mathrm{PCI}$, with a decrease and increase, respectively, before and after
1984 (Fig. 2D). As observed in the north NE Atlantic, the cumulative sums of diatom abundance increased before 1967 and globally decreased after 1967, with a local increase between 1979 and 1985 (Fig. 2D). In contrast, the cumulative sums of dinoflagellate abundance were relatively constant from 1958 to 1979, followed by an increase until 1985 and a decrease until 2002 (Fig. 2D).

Only the contribution of dinoflagellates to the PCI varied significantly over the period of study (Table 2, Fig. 3B), with an increase from 7.52 to $19.84 \%$. The residuals of the diatom/dinoflagellate contribution did not exhibit any significant trend (Table 2). In addition, cumulative sum analysis did not show any significant 
Table 4. Spearman's $\rho$ estimated between the contribution of diatoms and dinoflagellates in the NE Atlantic Ocean and (1) the North Atlantic Oscillation index (NAO) and (2) the sea surface temperature (SST) over the period 1958 to 2002 . ${ }^{*}: 5 \%$ significance level

\begin{tabular}{|lrccc|}
\hline & \multicolumn{2}{c}{ NAO } & \multicolumn{2}{c|}{ SST } \\
& Diatoms & Dinoflagel. & Diatoms & Dinoflagel. \\
\hline North & -0.193 & 0.133 & 0.271 & $-0.302^{*}$ \\
South & 0.055 & 0.096 & $0.368^{*}$ & -0.119 \\
\hline
\end{tabular}

local trend over the period of study (Fig. 3D). In contrast to what was observed for the NE Atlantic, this suggests that the ecosystem is still in evolution, with a constant contribution of diatoms to the PCI and an increasing contribution of dinoflagellates.

No relationship was observed between PCI and diatom and dinoflagellate abundance and the NAO winter index (Table 3). The same observation was true of the SST. There was no significant relationship between diatom and dinoflagellate contributions and the NAO winter index (Table 4). On the contrary, there was a significant positive correlation between the contribution of diatoms and SST (Table 4). As observed in the north NE Atlantic, no significant long-term trend was observed for the SST over the period of study in this area (Kendall's $\tau, \mathrm{p}<0.05, \tau=0.188$ ).

\section{North Sea}

In the northern North Sea, PCI and dinoflagellate abundance increased significantly globally (Fig. 4A, Table 1) and exhibited local trends (Fig. 4D). Diatom abundance did not exhibit any global trend. More specifically, the PCI cumulative sums decreased until 1985 and increased after this date. Dinoflagellate cumulative sums decreased before 1984 and subsequently increased, while diatom cumulative sums remained roughly steady (Fig. 4D). The contribution of diatoms and dinoflagellates significantly decreased from 71.24 to $50.12 \%$ and increased from 10.71 to $24.79 \%$, respectively (Table 2). The residuals of diatom/dinoflagellate contributions did not significantly vary over the period of study. These results suggest an evolution of the ecosystem towards a balance between diatoms and dinoflagellates over the last $45 \mathrm{yr}$, with the overall diatom/dinoflagellate contribution decreasing from 97.2 to $72.7 \%$ from 1958 to 2002 .

In the central and southern North Sea, PCI significantly increased, while dinoflagellate abundance significantly decreased in the southern North Sea, and diatom abundance did not show any long-term trend in either area (Fig. 4B,C, Table 1). In addition, PCI and diatom abundance revealed local trends in both areas (Fig. 4E,F). Diatom cumulative sums increased until
1968 and decreased afterwards, and PCI cumulative sums decreased until 1985 and subsequently increased. In the central North Sea, dinoflagellate cumulative sums were roughly steady over the period of study, with a drop between 1974 and 1989, while in the southern North Sea dinoflagellate cumulative sums increased until 1979 and decreased afterwards.

The contributions of diatoms and dinoflagellates, as the residuals, did not vary over the period of study in the central and southern North Sea (Table 2). In these areas, the ecosystem can thus be regarded as being in a stable state, in which diatoms dominate the phytoplankton community. The mean diatom and dinoflagellate contributions were 41.4 and $37.8 \%$ and 27.7 and $21.6 \%$ in the central and southern North Sea, respectively. The mean diatom/dinoflagellate contribution residuals were 30.92 and $40.60 \%$ in the central and southern North Sea, respectively.

There was a significant relationship between the NAO winter index and PCI in the northern North Sea (Table 3), but no relationship was observed between the NAO and diatom and dinoflagellate abundance in this area. Moreover, no significant relationship was observed between PCI, diatom and dinoflagellate abundance and NAO winter index in the central and southern North Sea (Table 3). SST and PCI were significantly correlated in the central and southern North Sea (Table 3), but no relationship was observed between SST and diatom and dinoflagellate abundance in these areas. In addition, no significant relationship was observed between PCI, diatom and dinoflagellate abundance and SST in the northern North Sea (Table 3). There was a significant, positive, long-term trend for the SST over the period of study in the central and southern North Sea (Kendall's $\tau$, $\mathrm{p}<0.05, \tau=0.267$ and $\tau=0.380$, respectively). Contrarily, no significant long-term trend was observed for the SST in the northern North Sea (Kendall's $\tau, \mathrm{p}<0.05$, $\tau=0.137)$.

\section{DISCUSSION}

\section{Multiple ecosystem states in the NE Atlantic and the North Sea}

We identified 3 states of the phytoplanktonic ecosystem throughout the NE Atlantic, suggesting differential temporal and spatial dynamics of the phytoplankton communities in geographically adjacent oceanic domains.

Firstly, a stable ecosystem was observed in the southern and central North Sea, where diatoms dominated the phytoplankton community. These areas belong to an epicontinental basin, where the influence of the North Atlantic water inflow is much weaker than in the 

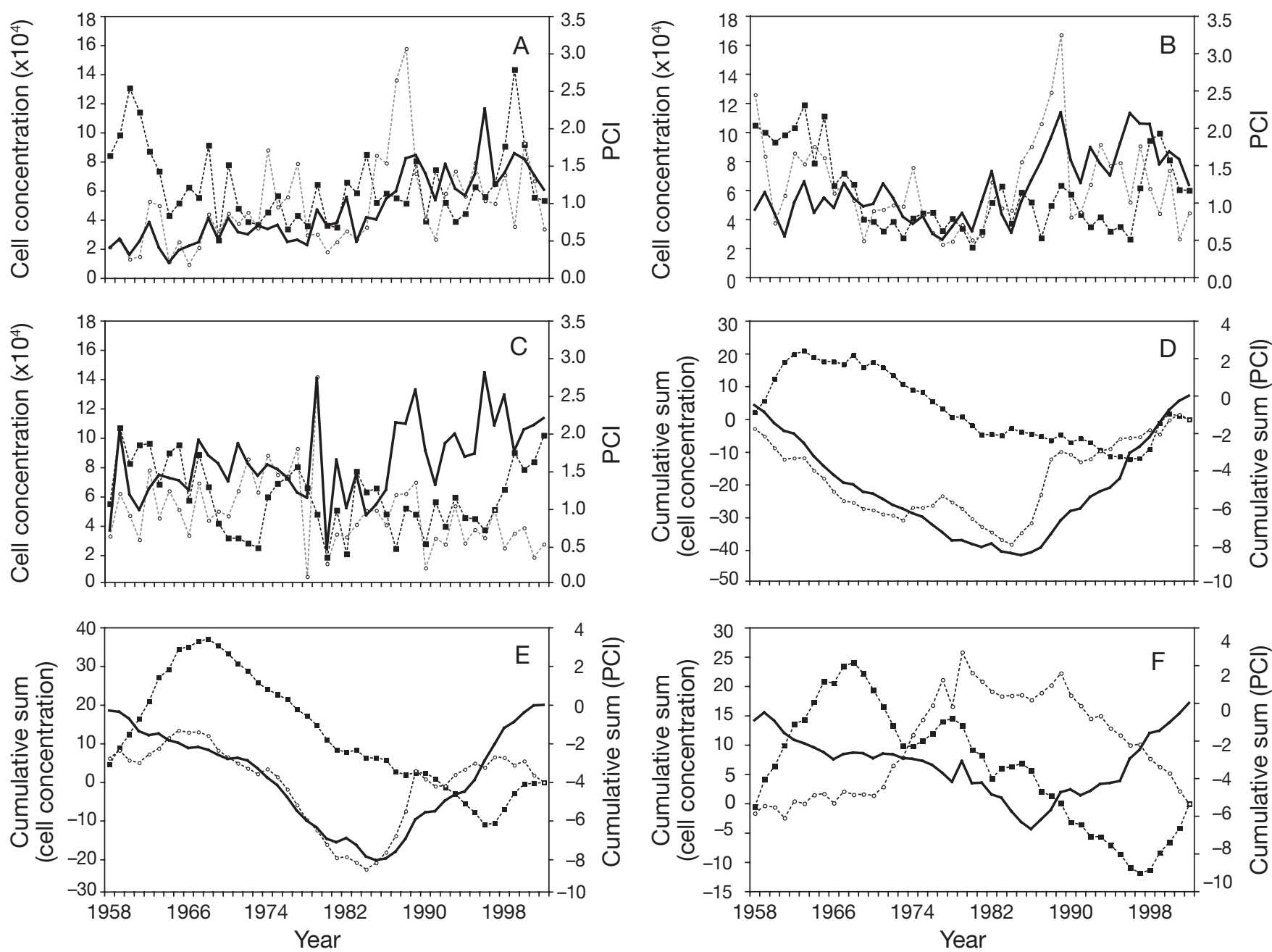

Fig. 4. Variation of the annual cell concentration of both diatoms ( $\bullet$ ) and dinoflagellates (O) and PCI (black line) in (A) the northern, (B) the central and (C) the southern North Sea, and the cumulative sum analysis for each parameter in (D) the northern, (E) the central and (F) the southern North Sea

northern North Sea (e.g. Turrell et al. 1992, Corten 1999). This area is also characterised by strong hydrodynamism and is increasingly impacted by eutrophication (Lancelot et al. 1997), 2 factors more favourable for diatoms than for dinoflagellates (e.g. Margalef 1973) and thus fully compatible with our observations.

Secondly, a currently evolving ecosystem was determined in the south NE Atlantic and the northern North Sea, with an increasing contribution of dinoflagellates contrasting, respectively, with a stable diatom population in the former region and a decreasing contribution of diatoms in the latter. These patterns can be related to the specific circulation patterns characterising these areas. The south NE Atlantic and the northern North Sea are indeed both highly influenced by the North Atlantic water inflow (Corten 1999). However, during the late 1980s, the NAO index was strongly positive and the strength of the westerly winds increased in the NE Atlantic, leading to an increase in the oceanic inflow into the North Sea (Drinkwater et al. 2003). Turrell et al. (1992) also suggested that the Atlantic inflow makes a major contribution to the input of generally warmer, nutrient-rich water into the northern North Sea. The resulting relatively warmer surface temperatures promote earlier, or more intense, stratification of the upper water column (Drinkwater et al. 2003), which, according to Margalef's (1973) hypothesis, would create an environment favouring the growth of dinoflagellates over the growth of diatoms.

Finally, in the north NE Atlantic we identified an ecosystem that has moved from one state to another, to reach a balanced state over the last decade. More specifically, our results suggest evolution from a diatom-dominated ecosystem to a more even distribution between diatoms and dinoflagellates and an increase in the proportion of other taxonomic groups such as phytoflagellates, as recently observed in other coastal ecosystems (Cloern 2001). 


\section{Phytoplankton communities and regime shift in the North Sea}

The different ecosystem states discussed in the above section are clearly related to a shift in the abundance and/or composition of phytoplankton communities. However, in our analyses, only the PCI provided evidence for the regime shift (defined as an abrupt shift from one dynamic regime to another, sensu Scheffer et al. 2001) observed in the North Sea during the period 1982 to 1988 (Reid et al. 2001, Beaugrand 2004). Dinoflagellates showed a shift in 1985, but only in the northern North Sea, and diatoms did not exhibit any evidence of a regime shift over this period. The observed discrepancy then suggests that the changes seen in PCI do not reflect changes in the community structure.

In addition, the features suggested to explain the regime shift in the North Sea by Beaugrand (2004) are acknowledged to influence the whole North Sea. We have shown here, however, that the dynamics of the northern North Sea clearly differ from those of the central and southern North Sea. This suggests that different driving processes might control the dynamics of the phytoplankton community. While this question needs to be addressed through in-depth investigations of the temporal fluctuations in the phytoplankton taxonomic composition, it is (1) beyond the scope of the present work and (2) still unfeasible, considering that the different taxonomic groups have not been surveyed over the same period. Thus, pico- and nanoplankton that contribute to the PCI cannot be identified in the CPR samples (Reid 1978). As a consequence, their potential contribution to the PCI space-time patterns is intrinsically not determinable, and might ultimately drive PCI variability and/or obfuscate the variability of the contributions of identifiable groups.

Finally, we stress that the decreasing contribution of diatoms/dinoflagellates along a north-south gradient could possibly be related to the increasing contribution of other taxonomic groups or smaller size fractions of phytoplankton, such as naked flagellates, which either break up when they impact the silk or disintegrate in formaldehyde (Batten et al. 2003), and thus contribute to PCI without being identifiable.

\section{Phytoplankton community composition and ecosystem structure and function}

The fluctuations in the 2 phytoplankton functional groups studied here are likely to impact the dynamics of the whole food web. The space-time differences in functional group contributions could, for instance, have an effect on zooplankton populations through their trophodynamics. Richardson \& Schoeman (2004) have thus shown a dominant bottom-up control within the plankton community in the NE Atlantic over time and space as the result of sea surface warming. However, we showed here that (1) the SST only exhibited a significant long-term trend in the central and southern North Sea from 1958 to 2002, (2) the PCI, the abundance of diatoms and dinoflagellates and the contribution of diatoms and dinoflagellates to the PCI were barely correlated to the NAO and SST (cf. Tables 3 \& 4 ), and (3) the significant correlations did not exhibit any distinct spatial pattern (cf. Tables $3 \& 4$ ). As a consequence, we suggest that (1) the so-called hydrometeorological forcing is likely to have short-term rather than long-term effects on phytoplankton communities in the eastern North Atlantic and the northern North Sea, (2) SST is likely to have long-term effects on phytoplankton communities in the central and southern North Sea and (3) the potential causal relationships between hydro-meteorological variables and phytoplankton abundance and community composition are strongly affected by the spatial location.

We finally stress that more detailed investigations of the relation between changes in phytoplankton composition and their potential effects on zooplankton communities are needed to achieve a deeper understanding of the mechanisms driving the observed patterns. Phytoplankton composition and thus zooplankton diet have indeed already been shown to influence hatching success (Laabir et al. 2001, Irigoien et al. 2002), growth and development (Koski et al. 1999) of calanoid copepods. As the production of copepods supports most food webs, directly affecting higher trophic levels and the biological pump of carbon (Ohman \& Hirche 2001), elucidation of the interplay between phytoplankton and zooplankton communities is vital for the future. The global relevance of this interrelationship is clear, considering the importance of these organisms in the context of climate change, anthropogenic impacts on ecosystems and the consequences on management of aquatic living resources.

Acknowledgements. Primary funding for this research was provided by UK DEFRA contract: 'Environmental change and biodiversity'. The CPR survey is supported by a funding consortium comprising governmental agencies from Canada, France, the Netherlands, Portugal and the USA. The survey depends on the voluntary cooperation of owners, masters and crews of merchant vessels that tow the CPRs on regular routes. We thank A. W. G. John for fruitful discussions and support, and the CPR survey teams, past and present. We also thank 5 anonymous reviewers for their constructive criticism and suggestions, which greatly improved the quality of the manuscript.

\section{LITERATURE CITED}

Barton AD, Green CH, Monger BC, Pershing AJ (2003) The continuous plankton recorder survey and the North 
Atlantic Oscillation: interannual- to multidecadal-scale patterns of phytoplankton variability in the North Atlantic Ocean. Prog Oceanogr 58:337-358

Batten SD, Walne AW, Edwards M, Groom SB (2003) Phytoplankton from continuous plankton recorder data: assessment of the phytoplankton colour index. J Plankton Res 25:697-702

Beaugrand G (2004) The North Sea regime shift: evidence, causes, mechanisms and consequences. Prog Oceanogr 60:245-262

Cloern JE (2001) Our evolving conceptual model of the coastal eutrophication problem. Mar Ecol Prog Ser 210: 223-253

Colebrook JM (1975) The continuous plankton recorder survey: automatic data processing methods. Bull Mar Ecol 8: 123-142

Colebrook JM, Robinson GA (1965) Continuous plankton records: seasonal cycles of phytoplankton and copepods in the northeastern Atlantic and the North Sea. Bull Mar Ecol 6:123-139

Corten A (1999) Evidence from plankton for multi-annual variations of Atlantic inflow in the northwestern North Sea. J Sea Res 42:191-205

Drinkwater KF, Belgrano A, Borja A, Conversi A and 5 others (2003) The response of marine ecosystems to climate variability associated with the North Atlantic Oscillation. In: Hurrell JW, Kushnir Y, Ottersen G, Visbeck M (eds) The North Atlantic Oscillation: climate significance and environmental impact. Geophys Monogr Ser 134: 211-234

Edwards M, Richardson AJ (2004) Impact of climate change on marine pelagic phenology and trophic mismatch. Nature 430:881-884

Edwards M, Reid PC, Planque B (2001) Long-term and regional variability of phytoplankton biomass in the Northeast Atlantic (1960-1995). ICES J Mar Sci 58:39-49

Fromentin JM, Stenseth NC, Gjosaeter J, Johannessen T, Planque B (1998) Long-term fluctuations in cod and pollack along the Norwegian Skagerrak coast. Mar Ecol Prog Ser 162:265-278

Hays GC, Warner AJ (1993) Consistency of towing speed and sampling depth for the continuous plankton recorder. J Mar Biol Assoc UK 73:967-970

Hays GC, Clark DR, Walne AW, Warner AJ (2001) Large scale patterns of zooplankton abundance in the NE Atlantic in June and July 1996. Deep-Sea Res II 48:951-961

Hurrell JW (1995) Decadal trends in the North Atlantic Oscillation: regional temperatures and precipitation. Science 269:676-679

Ibañez F, Fromentin JM, Castel J (1993) Application de la méthode des sommes cumulées à l'analyse des séries chronologiques océanographiques. CR Acad Sci Paris 316: $745-748$

Irigoien $\mathrm{X}$, Harris RP, Verheye HM, Joly P and 14 others (2002) Copepod hatching success in marine ecosystems with high diatom concentrations. Nature 419:387-389

Johns DG, Edwards M, Richardson A, Spicer JI (2003) Increased blooms of a dinoflagellate in the NW Atlantic. Mar Ecol Prog Ser 265:283-287

Kendall M (1976) Time-series, 2nd edn. Charles Griffin, London

Kendall M, Stuart A (1966) The advanced theory of statistics. Hafner, New York

Koski M, Engstrom J, Viitasalo M (1999) Reproduction and survival of the calanoid copepod Eurytemora affinis fed with toxic and non-toxic cyanobacteria. Mar Ecol Prog Ser 186:187-197

Laabir M, Buttino I, Ianora A, Kattner G, Poulet SA, Romano G, Carotenuto Y, Miralto A (2001) Effect of specific dinoflagellate and diatom diets on gamete ultrastructure and fatty acid profiles of the copepod Temora stylifera. Mar Biol 138:1241-1250

Lancelot C, Rousseau V, Billen G, van Eeckhout D (1997) Coastal eutrophication of the Southern Bight of the North Sea: assessment and modeling. In: Ozsoy E, Mikaelyan A (eds) Sensitivity of North Sea, Baltic Sea and Black Sea to anthropogenic and climatic changes. NATO-ASI Ser 2, 27:439-454

Leterme SC, Edwards M, Seuront L, Attrill MJ, Reid PC, John AWG (2005) Decadal basin-scale changes in diatoms, dinoflagellates, and phytoplankton color across the North Atlantic. Limnol Oceanogr 50:1244-1253

Lindley JA, Batten SD (2002) Long-term variability in the diversity of North Sea zooplankton. J Mar Biol Assoc UK 82:31-40

Lindley JA, Williams R (1980) Plankton of the Fladen Ground during FLEX 76. II. Population dynamics and production of Thysanoessa inermis (Crustacea: Euphausiacea). Mar Biol 57:79-86

Lindley JA, Reid PC, Brander K (2003) Inverse relationship between cod recruitment in the North Sea and young fish in the continuous plankton recorder survey. Sci Mar 67:191-200

Margalef R (1973) Assessment of the effects on plankton. In: Pearson EA, De Fraja Frangipane E (eds) Marine pollution and marine waste disposal. Proceedings of the 2nd international Congress, San Remo, Dec 17-21, 1973. Pergamon Press, Oxford, p 301-306

Ohman MD, Hirche HJ (2001) Density-dependent mortality in an oceanic copepod population. Nature 412:638-641

Planque B, Taylor AH (1998) Long-term changes in zooplankton and the climate of the North Atlantic. ICES J Mar Sci 55:644-654

Reid PC (1978) Continuous plankton records: large-scale changes in the abundance of phytoplankton in the North Sea from 1958 to 1973. Rapp P-V Reun Cons Int Explor Mer 72:384-389

Reid PC, Edwards M (2001) Long-term changes in the pelagos, benthos and fisheries of the North Sea. Senckenb Marit 31:107-115

Reid PC, Robinson GA, Hunt HG (1987) Spatial and temporal patterns of marine blooms in the northeastern Atlantic and North Sea from the continuous plankton recorder survey. Rapp P-V Reun Cons Int Explor Mer 187:27-37

Reid PC, Borges M, Svendsen E (2001) A regime shift in the North Sea circa 1988 linked to changes in the North Sea horse mackerel fishery. Fish Res 50:163-171

Richardson AJ, Schoeman DS (2004) Climate impact on plankton ecosystems in the Northeast Atlantic. Science 305: 1609-1912

Robinson GA (1970) Continuous plankton records: variation in the seasonal cycle of phytoplankton in the north Atlantic. Bull Mar Ecol 6:333-345

Scheffer M, Carpenter S, Foley JA, Folke C, Walker B (2001) Catastrophic shifts in ecosystems. Nature 413:591-596

Sims DW, Reid P (2002) Congruent trends in long-term zooplankton decline in the North-East Atlantic and basking shark (Cetorhinus maximus) fishery catches off west Ireland. Fish Oceanogr 11:59-63

Sokal RR, Rohlf FJ (1995) Introduction to biostatistics, 3rd edn. Freeman, New York

Turrell WR, Henderson EW, Slesser G, Payne R, Adams RD (1992) Seasonal changes in the circulation of the northern North Sea. Cont Shelf Res 12:257-286

Warner AJ, Hays GC (1994) Sampling by the continuous plankton recorder survey. Prog Oceanogr 34:237-256

Zar JH (1996) Biostatistical analysis, 3rd edn. Prentice-Hall, Upper Saddle River, NJ

Submitted: October 6, 2004; Accepted: October 16, 2005

Proofs received from author(s): March 22, 2006 